\title{
Anna Griva*
}

\section{The Reception of Sappho in Italian Renaissance: Biographical Tradition and Early Editions of the Sapphic Works}

In the $16^{\text {th }}$ century Sappho came to the forefront, initially through the early editions of ancient writers who made references to her verses or to her life. In 1508 Aldus Manutius published Dionysius of Halicarnassus, whose work De compositione verborum (XXIII) contains the Ode to Aphrodite (fr.1) ${ }^{1}$, where the author admires her for her noble style. Also, the work On the Sublime contains the fragment 31, where the unknown writer records that the poetess knows the

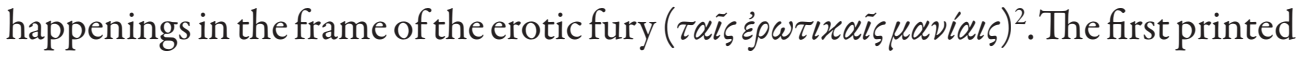
version of this book was made in $1554^{3}$. In 1560 Henri Estienne proceeded to the publication of nine Greek lyric poets, including Sapphic fragments ${ }^{4}$, while

\footnotetext{
*Faculty of Italian Language and Literature, National and Kapodistrian University of Athens (annagriva@hotmail.com).

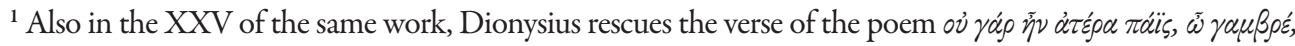

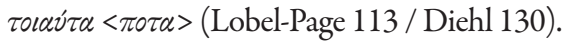

${ }^{2}$ Accordingly, Plutarch (Amat. 436) commented the dolorous passion of Sappho, referring to the fr. 31: $2 \xi \xi 0 v$

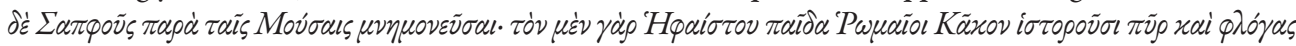

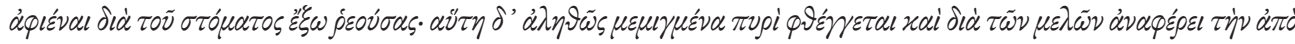

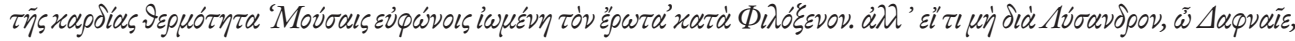

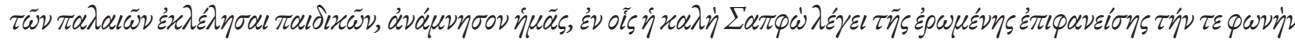

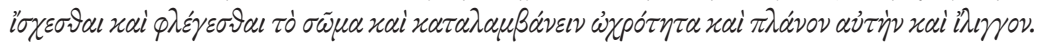

[It is worth mentioning Sappho next to the Muses. Because Romans say that the son of Hephaestus, Cacus, left out of his mouth fire and flames. So she really talks by mixing her speech with fire and with her poems she talks about the heat of the heart, "healing love with the melodious Muses", according to Philoxenus. But Daphnaeus, if you have not forgotten your old love, remind us of the poem, where the beautiful Sappho says that once the beloved appears, her voice is lost and the body is flaming and becomes pale and gripped of frenzy and vertigo.]

${ }^{3}$ It is published by Francis Robortello in Basel. The same year it is published in Venice by Muret, in his comments on Catullus.

${ }^{4}$ Estienne in the edition of Anacreon's poems (1554) had already included Sappho's fr.1, while in the second edition of the same book he added fr.31 together with the variation of Catullus (Ode 51). See Morrison, "Henri Estienne and Sappho", 388-391.
} 
in 1566, in the second edition of the same volume, he widened even more the corpus of the Sapphic poems, through including apart from fr. 1 and fr. 31 another 40 fragments by the ancient poetess 5 .

Though, apart from Sappho's own work ${ }^{6}$, there was a great corpus of literary texts about her life and art, which was preserved in the Renaissance, also through ancient sources. In particular, Ovid in Heroides, in the imaginary letter of the poetess to $\mathrm{Phaon}^{7}$, presents her to commit suicide because of her love for him ${ }^{8}$, while she mentions that she had loved some women (XV, 17 and 201) $)^{9}$ When in the early $15^{\text {th }}$ century this work became known again ${ }^{10}$, it was considered to be a genuine Sappho's letter and influenced the image that scholars and artists formed about her ${ }^{11}$. The same image of the enamored Sappho who committed suicide for Phaon was given by Photius in his Library: the Library, which was first printed in 1601 by David Hoeschelius, influenced the reception of Sappho, because the Renaissance scholars could find in this work valuable informations about ancient writers and their vanished works. Another view of Sappho, the view of a sister who is worried about her brother, emerged also Renaissance through Herodotus, whose work was first printed by Aldus Manutius in 1502 in Venice: the ancient

5 This edition of Estienne is the most complete until the publication of Wolf in 1733. Furthermore in the edition of 1556 a three-page biography of Sappho is included, in which the publisher refers to the poet's reputable life until the death of her husband, to her beloved girls (puellas amatas) and $\tau 0$ Phaon, the love for whom led her to her tragic end. The publication closes with Ovid's letter 15, from Sappho to Phaon.

${ }^{6}$ The survived work of Sappho in that period contains the verses which are related mainly to the expression of the erotic feelings and to the deities that control these feelings, or to the poetic genre of the wedding songs: Renaissance responds to these themes through the erotic, as well as through the revival of the wedding poems and paintings, mainly in frescoes, which were a way of welcoming the newlyweds to their new house (McKinney Brenner, The inquiring eye: Classical mythology in European Art, 26).

${ }^{7}$ Poliziano writes a comment on this letter of Ovid (see Lazzeri, Commento inedito all'epistola ovidiana di Saffo a Faone), which shows the effect of this text on the Renaissance poets.

${ }^{8}$ Strabo $(\mathrm{X}, 452)$ refers to the poet's suicide from the rocks of Lefkata because of her love for Phaon, as recorded in a comedy by Menandros (Fr. 258 Kock). See also Palaifatus 48, Aelian. VI XII 18, Athenaeus II, 69 where Phaon was a local deity, corresponding to Adonis, and also a beloved of Aphrodite, while the relationship between Phaon and Sappho was a misunderstanding of the comedians.

${ }^{9}$ See Ov. Trist. II 365.

${ }^{10}$ The editio princeps took place in 1471 by Baldassarre Azzoguidi in Bologna. A lot of Venetian editions was then published in 1482, 1492, 1495, 1499 (Andreadis, Sappho in Early Modern England: Female SameSex Literary Erotics 1550-1714,29), while in the $16^{\text {th }}$ century the fame of the work was expanded though new editions (Heroides, Amores, Ars amatoria, Remedia amoris, Medicina fédiquee, Aldus Manutius and Andrea Torresanus, Venice, 1515; Heroides, Amores, Ars amatoria, Remedia amoris, Medicina faciei femineae, Melchior Sessa, Venice, 1527; Heroides, Amores, Ars amatoria, Remedia amoris, Sebastianus Gryphius, Lyon, 1554; Heroides, Ibis, Amores, Ars amatoria, Remedia amoris, Ioannes Saurius, Frankfurt, 1599)

${ }^{11}$ Most, "Reflecting Sappho”, 19. 
writer refers to Sappho (II, 135) at the point where he mentions the adventure of her brother Charaxus with the courtesan Rhodopis. Plato, who is also playing a key role in shaping the intellectual environment of the Italian Renaissance, calls Sappho beautiful (Phaed. 235c) ${ }^{12}$. The beauty of Sappho's art was emphasized in Alexiad of Anna Comnena (XIV, XV), a work printed in 1602 by David Hoeschelius, which was of great interest in the late Renaissance world, because it was coming from a female pen of the Middle Ages. Her beauty was also praised in another medieval work, the Synopsis historion by George Cedrenus, printed by Wilhelm Xylander in 1566: the Byzantine historian calls Sappho as the first of the Muses. Catullus (51) made a poetic adaptation of the fragment 31 , where the beloved he is referring to is a Lesbian ${ }^{13}$ and his love for her is causing to him the same symptoms as the symptoms of Sappho in the above mentioned fragment. The poems of Catullus were first published in Venice by Vindelinus de Spira in 1472 and had a significant impact on the Renaissance ${ }^{14}$. Horace ${ }^{15}$ called her in his Letters $(1: 19,28)$ mascula Sappho, that is to say, male Sappho, a phrase which, beside the erotic suggestions, implies that the art and the momentum of her verses were often attributed to the male writers, since as a poet he was admiring her and was influenced by her work ${ }^{16}$.

In $S u d a^{17}$ there is a reference to two different persons with the same name Sappho: the first is Sappho from Eressos, married to Kerkylas and mother of Cleïs, while the second is Sappho from Mytilene, who was playing a lyre and committed suicide by falling into the sea, because of her love for Phaon. The

\footnotetext{
${ }^{12}$ In an epigram of the Palatine Anthology attributed to Plato (IX 506), Sappho is characterized as the tenth Muse, while Aelian in his Varia Historia (Book 1, 128) also states that Plato called her wise, and that there was a second Sappho courtesan, apart from the poet.

${ }^{13}$ Lesbian is the protagonist in the poems 25 of 116 by Catullus. These reflect the thematic and metric influences of sapphic poetry on him $(11,51)$.

${ }^{14}$ Famous in that period was the poetic composition of the French poet Pierre de Ronsard (1560), according to Catullus standards.

${ }^{15}$ Horace, being one of the ancient writers printed so early, exerted a special influence in the following years: Horace's editio princeps takes place in Venice around 1471-2 (Braund, "The Metemphychosis of Horace: the reception of the satires and epistles", 368).

${ }^{16}$ See the second Ode by Horace, where he refers that even the souls of the dead people hear with admiration her songs. About the influences of Sappho on Horace see Nagy, "Copies and Models in Horace Odes 4.1 and 4.2", 415-426.

${ }^{17}$ Already in the 15th century Suda is copied because of its practical use by the students of Greek (see the manuscript Laur.55.1), but also because of its widespread use by scholars such as Francesco Filelfo or Poliziano (Wilson, From Byzantium to Italy: Greek Studies in the Italian Renaissance, 43, 58, 121). At the end of the 15th century, Demetrius Chalcocondyles published the same work in Florence, which exceeds 1000 pages (ibid: 111): Manutius republished the same work in Venice (a re-edition of the editio princeps) in 1514.
} 
first Sappho was an aristocratic lyrical poet and the inventor of the plectrum, and had a "shameful" friendship with Atthis, Telesippa and Megara ${ }^{18}$. Earlier, Aelian in his Varia Historia (Book XII) also talked about two different persons, a courtesan and a poet. It seems that Aelian attempted to respond to the slanders against Sappho, which had already appeared in the years of the late antiquity: the comedians of the Middle Attic Comedy, as Amphis and Antiphanes, wrote works with the title Sappho, of which only fragments have been survived. In these works, although we cannot have a clear knowledge of the content, it seems that Sappho is presented as a courtesan, something that does not appear in works of the previous years. Also, Plato the Comedian in his work Phaon, as well as other fragments of the Attic comedy ${ }^{19}$, talks about the poet's love with Phaon ${ }^{20}$. The positions of the comedians seem to influence several Latin writers: for example, Tatian, one of the earliest Fathers of church in his work Oratio ad Graecos (Address to the Greeks) (33-34) presented the poet as an erotomaniac and lover of women ${ }^{21}$. The opposite view was given by Maximus Tyrius (Dissertations, XXIV 7-9), who interpreted Sappho's relationship with women of her milieu in a spiritual base, like the relationship of Socrates with his students. Also, according to Aelian, Solon asked to learn a song of Sappho and then "he could die" (Stob. Anth. 3:29, 58); this episode shows the admiration of antiquity for Sappho's work. Palatine Anthology also contains a lot of eulogistic epigrams (VII 14, 15, 16, IX 251)22.

The fact that Sappho was an object of admiration and interest in antiquity, but also in the years to come, until the Renaissance, is also apparent by the fact

\footnotetext{
${ }^{18}$ Suidae lexicon, s.v. "Sappho $(1,2)$ ".

19 These fragments are included in: Edmonds 1957. The story of Sappho's love and suicide is repeated by Strabo (Geogr. I, 2.9).

${ }^{20}$ Obviously, a confusion has gradually emerged between the biographies of Sappho and the myth of Aphrodite's love with Phaon, which has much in common with Adonis's myth. In the myth Phaon appears as an ugly and old shipyard in Mytilene, who was transferring inhabitants on the opposite coast of Asia Minor, until Aphrodite came to his boat disguised as an old lady. Phaon transferred her to Asia Minor and did not accept a fee. In return, Aphrodite gave him an ointment, which transformed him into a beautiful young man and he fascinated many women with his beauty. This myth is one of the characteristic folk fables that have been encountered since ancient times about the quest of eternal youth and beauty, which later alchemists claimed that can be attained through 'elixir of life'. This myth has often been the subject of the vase painting, which means that it was very popular. Characteristic is the depiction of the young Phaon surrounded by the Nymphs, Eros, Peitho and Himeros, in an ancient Attic red-figured cup, about 410 BC, exhibited at the National Museum of Palermo.

${ }^{21}$ Seneca reports that Sappho was a courtesan (Letters to Lucilius, 88, 37).

${ }^{22}$ See Steph. Meleagr. IV. I6.
} 
that there are numerous depictions of her through the visual and plastic arts ${ }^{23}$. Her suicide was one of the objects of classical art, such as in the Basilica of the 1st century BC in Rome, near Porta Maggiore ${ }^{24}$. Also, Christodorus in the Ekphrasis ( AP II 69-71) described her statue in Constantinople, as follows:

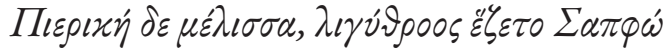

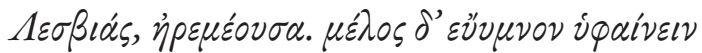

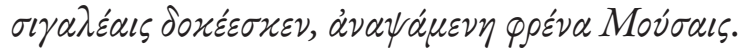

[The Pierian Bee, Sappho the Lesbian, with the sweet voice sat, serene, knitting a graceful song after the silent Muses put a flame in her heart.]

In the medieval manuscripts, Sappho was presented surrounded by books and musical instruments, while in an engraving of 1501, decorating an early version of Ovid's Heroides, appeared as a priestess making a libation over a sacred fire encircled by women playing music ${ }^{25}$. In later years, Sappho was portrayed in the Parnassus of Raffaello in the Vatican (Stanze di Raffaello, about 1511), along with the nine Muses, on the mountain of Parnassus, where Apollo is the leader: in Renaissance Sappho was widely considered as the tenth Muse. It is characteristic that in this work the name of the poet is written on a papyrus which she holds in her hands, so that there is no doubt about her identity, but also her distinct position in the poetic universe is emphasized ${ }^{26}$.

Boccaccio in De Claris Mulieribus (1361-2) presented her as a marvelous skilled model in poetry. Petrarca mentioned Sappho several times in his works. In the poem Trionfo d Amore (IV, 25-27), written about in 1352, he described Sappho as a young girl who sings sweet songs among other great poets of antiquity:

\footnotetext{
${ }^{23}$ For Sappho's depictions of vases, statues and coins see Reynolds, The Sappho Companion, 69.

${ }^{24}$ Hallett, "Sappho and her Social Context: Sense and Sensuality", 448.

${ }^{25}$ Reynolds, The Sappho Companion, 83-84.

${ }^{26}$ See Il Codice di Giulia Solinga, BMCVe, ms Cicogna 270, cf. 1r-12v, Il processo in Parnaso in difesa di Sara Copio Sullam, which records a fantastic trial in the Parnassus to defend the poet Sara Copio Sullam against her enemies. Among the judges is Sappho. It seems that the ancient poet became through her art a kind of goddess, taking a seat next to the Muses and Apollo. Such a picture reminds us of the judges of Hades, Minos, Radamanthes and Aiacus: as they have the eternal role of the judgemnet of the souls, so the poets-judges define what will be called poetry over the centuries.
} 
Una giovene Greca a paro a paro

coi nobili poeti iva cantando,

et avea un suo stil soave e raro.

[A young Greek next to

the noble poets singing,

with rare and sweet writing]

In the tenth Eclogue (85-89) of the Latin work Carmen bucolicum (13461357) Petrarca envisioned Sappho as a capable, educated young girl (doctapuella), singing love (cantabat amoris) and dancing among men (choris doctorum immixta virorum). Christine de Pisan in Le Livre de la cité des dames (1404) mentioned her as an example of the cultivated woman, and spoke of women's rights, without being interested in the subject of Sapphic love ${ }^{27}$.

In northern Italy, during the Renaissance, a new trend emerged: catalogues of women ${ }^{28}$ were compiled, where Sappho was always included as an exemplary case of personality and talent. Many of these catalogues were made after women's commissions. For example, Margherita Cantelmo, although she did not know Latin, commissioned two catalogues written in Latin, in order to address to a cultivated male audience demonstrating the spiritual abilities of women. In 1480, Bartolommeo Goggio, in order of Eleonora d'Aragona, wrote his own defense of women De laudibus mulierum (British Library Add Ms. 17415). Goggio wrote that Sappho of Eressos had six pupils and they were all more capable than the men of those years, while at the same time there was also Sappho of Mytilene, who invented the Sapphic verse and she was considered to be equivalent to the Muses, who were the source of her poetic art. Indeed, it was emphasized in this work that Sappho had spiritual potentials as few male poets of her time. The Sappho of Mytilene fell in love with Phaon, while her verses are not inferior to Ovid, according to Goggio ${ }^{29}$.

Also, in Renaissance it was known that Sappho was an outstanding musician who renewed the musical tradition: in Suda it is said that she invented the plectrum, and there are also other references that describe the relationship of

\footnotetext{
${ }^{27}$ Reynolds, The Sappho Companion, 82-83.

${ }^{28}$ On these catalogues see Kolsky, The Ghosts of Boccaccio: Writings on Famous Women in Renaissance Italy; Franklin, Boccaccio's Heroines: Power And Virtue in Renaissance Society, 122-130.

${ }^{29}$ Penrose, “Sappho’s Shifting Fortunes from Antiquity to the Early Renaissance”, 430-431.
} 
her poetry with the music ${ }^{30}$. Ariosto in Orlando Furioso (Canto 20, I, 7-8) referred to both her and Corinna in a similar way, as two poets who are distinguished for their abilities and their education (furon dotte) as well as for their fame (splendono illustri). In England Thomas More composed epigrams, where he referred to Sappho as the tenth Muse (Lesbica iam Sappho Pieris est decima) ${ }^{31}$, without mentioning her erotic life.

In parallel to the biographical tradition concerning Sappho, which was formed in the Renaissance, it would be advisable to study in detail the early editions of ancient Greek writers containing Sapphic verses. In this way an outline of these two factors which determined the 'presence' of Sappho in the Italian Renaissance will have been given. Next the first editions of these works -published from the mid $15^{\text {th }}$ century until the mid $16^{\text {th }}$ century- are written down in chronological order. Additionally certain references are presented to both important editions published later and the handwritten sources on which the editions were based.

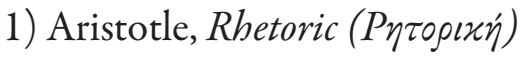

In 1475 this work was published in Paris (Aristotle, Rhetorica, Ed. Iohannes Stoll and Petrus Caesaris Wagner), in a translation of George of Trebizond (translated in 1443-1446). Between 1495 and 1498 Aldus Manutius published five volumes of Aristotle, which were completed in 1506-1507 with the works Poetics and Rhetoric (Aristotle, Rhetorica, Poetica, Ed. Demetrius Ducas in Rhetores Graeci). Moreover, quite early, long before the publication of Manutius, there were many manuscripts of the Rhetoric: Vittorino da Feltre states that in his time Aristotle's numerous manuscripts were easily accessible in Florence ${ }^{32}$, while he was holding several volumes with works of the philosopher. The same fact is also testified by a letter by Filelfo to Vittorino, dated in 1430, which refers to a loan of Aristotle's 'dialectical works'. Also, a copy of the Rhetoric (Paris sup.gr. 1285), which was in the possession of Filelfo, had Vittorino's (ex-libris) stamp ${ }^{33}$; this indeed shows the early dissemination of the Aristotelian works among the scholars. Rhetoric includes the Sapphic fragment Lobel-Page 137 (Arist. Rhet. 1367a) ) $^{34}$.

\footnotetext{
${ }^{30}$ See also Ath. 635 and Plut. De Mus. II 36d.

${ }^{31}$ Epigr. 15 (Miller).

${ }^{32}$ Wilson, From Byzantium to Italy: Greek Studies in the Italian Renaissance, 41.

${ }^{33}$ Wilson, From Byzantium to Italy: Greek Studies in the Italian Renaissance, 44.

${ }^{34}$ In the first book $(9,20)$, Aristotle refers to the aforementioned fragment, though which it is supposed that
} 
2) Palatinate Anthology or Anthology of Planudes or Greek Anthology

Janus Lascaris in 1494 printed the Greek Anthology following the form of the work that Maximus Planudes had recorded in $1229^{35}$. The dissemination of Greek Anthology among the poets is also illustrated by the fact that Poliziano wrote epigraphs imitating the models of Greek Anthology ${ }^{36}$. In the second half of the 15th century, Demetrius Chalcocondyles participated in the transcription of a copy (Laur. 31.28) of Greek Anthology ${ }^{37}$. In 1503 Aldus Manutius published the Greek Anthology with the Latin title Florilegium, which in Latin means anthology (Florilegium diversorum epigrammatum in september libros, 1503). In Greek Anthology the following poems, attributed to Sappho, are included:

Diehl 158 [Anth. Pal. 7.489 (Plan.)]

Diehl 159 [Anth. Pal. 7.505 (Plan.)]

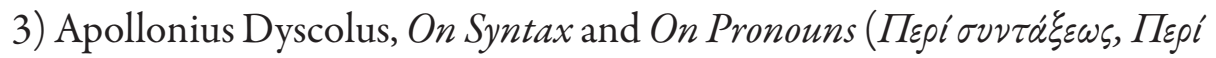
$\dot{\alpha} \nu \tau \omega \nu \nu \mu \iota \tilde{\omega} \nu)$

In February 1495 Aldus Manutius published in Venice the four books of the work On Syntax (Apollonii gramatici, De constructione orationis libri quatuor). This work contains the Sapphic fragment Lobel - Page 33/ Diehl 9 / Bergk 9 / Cox 9 (Ap. Dysc. Synt., 3.247). The same work was published by E. Boninus in 1515 in Florence (Apollonii alexandrei de constructione).

4) Eustathius of Thessalonica, Commentaries on Homer's Iliad and Odyssey

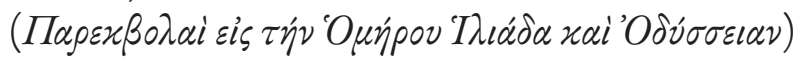

The comments of Eustathius on the Homeric epics, in which the Sapphic fragment Lobel-Page 34 / Voigt 34 / Bergk 3 / Cox 4 (Eust. Il. 729 20) is included,

Sappho answers to Alcaeus, when he writes that he cannot speak to her (Alc. 55). She tells him that he feels so

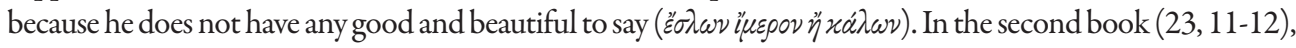
Aristotle reports that the Mytileneans honor Sappho, although she is a woman, and that Sappho said that $\tau \dot{0}$

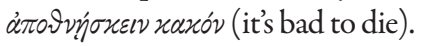

${ }^{35}$ See the autograph of Planudes (Marc.gr. 481), which was a part of the collection of Bessarion. However, Lascaris seems to follow another manuscript and not the earlier Palatine Anthology (Wilson, From Byzantium to Italy: Greek Studies in the Italian Renaissance, 113).

${ }^{36}$ Wilson, From Byzantium to Italy: Greek Studies in the Italian Renaissance, 115. Poliziano seems to know Greek Anthology though the collection of epigrams found in the manuscript MS Vaticanus gr. 1373 of Andronicus Callistus (Wilson, From Byzantium to Italy: Greek Studies in the Italian Renaissance, 126).

${ }^{37}$ Wilson, From Byzantium to Italy: Greek Studies in the Italian Renaissance, 130. 
were particularly appreciated in the educated circles of the Renaissance: we know that Bessarion obtained a new manuscript of these comments on Iliad (Marc. 461 and 462), copied and transported to Italy ${ }^{38}$. Later, Demetrius Chalcocondyles, wishing to study the Homeric works in more detail, also used the commentaries of Eustathius $^{39}$. In 1496, Aldus Manutius published in Venice, as an aid to the students of Greek, Thesaurus cornucopiae et horti Adonidis, which was largely based on Eustathius' comments, alongside other sources, such as Etymologicum Magnum ${ }^{40}$.

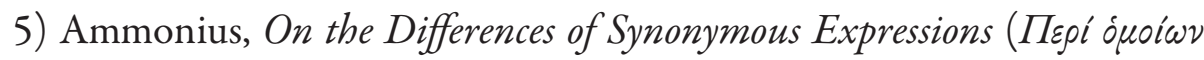

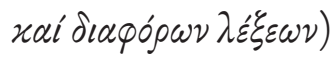

The first edition of the work was done in Venice in 1497 by Aldus Manutius and was included in the Dictionarium Graecum (Ed. Johannes Crastonus, 1497). In this work of Ammonius, the Sapphic fragment Lobel-Page 123 / Diehl 15 / Cox 18 (Amm. 75) is included.

The work On Pronouns, which includes the Sapphic fragments Lobel-Page 32 / Diehl 10 / Bergk 10 / Cox 10 (Ap Dysc. Pron. 144a), Lobel-Page 40 / Diehl 8 / Bergk 7, 8 / Cox 8 (Ap. Dysc. Pron. 104c) and Lobel-Page 41 / Diehl 12 / Wharton 14 (Ap. Dysc. Pron. 124c), survived in a unique manuscript in the codex Parisinus graecus 2548 (currently in the National Library of France), together with two other works of the same author (On Conjunctions, On Adverbs). So it seems that the Sapphic fragments that survive in the work On Pronouns were not widely known in the 16 th century.

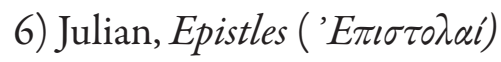

In 1499, Manutius printed in Venice the Epistolae diversorumphilosophorum. In this corpus of the epistles made by Marcus Musurus the letters of Julian are included: more specifically, Julian records the Sapphic fragment Lobel-Page 48 / Diehl 48 (Ep.183).

\footnotetext{
${ }^{38}$ Wilson, From Byzantium to Italy: Greek Studies in the Italian Renaissance, 74.

${ }^{39}$ Wilson, From Byzantium to Italy: Greek Studies in the Italian Renaissance, 111. The comments of Eustathius on the Iliad also exist in the manuscript of Biblioteca Laurentiana 59.2-3.

${ }^{40}$ Wilson, From Byzantium to Italy: Greek Studies in the Italian Renaissance, 154
} 


\section{7) Etymologicum Magnum}

The Etymologicum Magnum, composed by an anonymous lexicographer in Constantinople around 1150, with main sources the two etymological dictionaries Etymologicum Genuinum ${ }^{41}$ and Etymologicum Gudianum, was first published in Venice in 1499 by Zacharias Calliergi and Nikolas Vlastos, financed by Anna Notara. This dictionary contains the following Sapphic fragments:

Lobel-Page 36 / Diehl 20 (Et. Mag., 485.41ss)

Lobel-Page 37 / Diehl 14 / Wharton 17 / Cox 17 (Et. Mag. 576.23ss)

120LP / Diehl 108 / Cox 69 (Et. Mag. 2.43)

Lobel-Page 126 / Diehl 134 (Et. Mag. 250.10s)

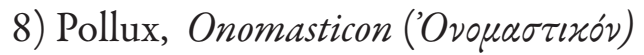

The first editions of the Onomasticon were made in the first half of the 16th century, containing only the Greek text (Aldus Matunius, Venice, 1502, B. Junta, Florence, 1520, S. Grynaeus, Basel, 1536). This work includes the Sapphic fragment Lobel Page 54 / 56Diehl / Cox 61 (Poll. 10, 124).

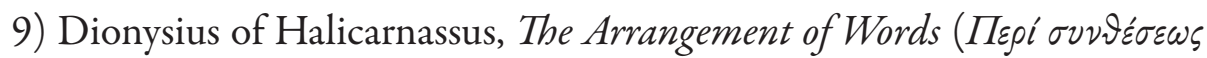

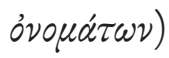

In 1508, Aldus Manutius published in Venice some works by Dionysius of Halicarnassus, (Dionysius Halicarnasseus, Ars Rhetorica \& De Compositione Verborum, Venezia, Ed Demetrius Ducas in Rhetores Graeci). In Dionysius' work The Arrangement of Words (D.H. Comp. 23) the Hymn to Aphrodite (Lobel-Page 1 / Voigt 1 / Diehl 1 / Bergk 1 / Cox 1), which is the only complete Sapphic poem found, survives. The Sapphic fragment Lobel-Page 113 / Diehl 130 (D.H. Comp. 25) is also included in the same work.

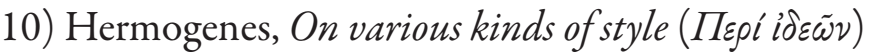

In the rhetorical corpus that Manutius published in two tomes in 1508 (Rhetorica), Hermogenes is included.

\footnotetext{
${ }^{41}$ Etymologicum Genuinum, which was composed by an anonymous lexicographer in Constantinople around the middle of the 9th century based on the texts of previous lexicographers and commentators, survived only in two manuscripts of the 10th century: Codex Vaticanus Graecus 1818 (= A) and Codex Laurentianus Sancti Marci 304 (= B; AD 994), which were discovered in the 19th century and to a large extent remain unpublished.
} 
In his work On various kinds of style the Sapphic fragments Lobel-Page 105a / Voigt 105a / Diehl 116 / Bergk 93 / Cox 90 (Syrian. In Hermog, Id. 1.1) and Lobel-Page 118 / Diehl 103 (Hermog. Id. 2.4) are included.

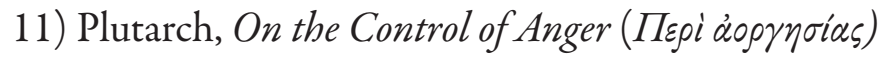

Aldus Manutius, with the main responsibility of Demetrius Doukas, published the work Moralia in 1509 in Venice in a huge tome of 1050 pages: this work includes the book De cobibenda ira (On the Control of Anger) in which there is the Sapphic fragment Lobel-Page 158 / Diehl 126 / Cox 25 (Plut. De cohib. Ira 456e) ${ }^{42}$.

12) Galen, Exhortation to the Study of the Arts especially Medicine: To

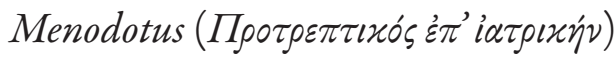

Already in the 9th c. Galen's works were widespread due to the practical nature of his work; so several translations of these works were circulated ${ }^{43}$. From the Middle Ages his works were survived in Latin (the most popular are the Latin versions of the text according to Burgundio of Pisa and Nicholas of Reggio). Later, Niccolò Leoniceno (1428-1524) was one of Galen's translators, and he accompanied his translation with an extensive introduction, while he also wrote an essay on the scientific method of Galen. Indeed, when Calliergi and Vlastos prepared the volume of Galen (1500), they obtained texts from Leoniceno ${ }^{44}$. Manutius published in Venice the corpus of the works of Galen in 1525 (Omnia Opera). Galen's Exhortation contains the Sapphic Lobel-Page -50 / Diehl 49.

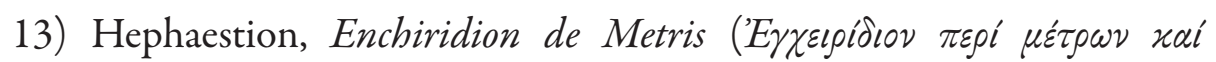
$\pi \circ \imath \mu \alpha \dot{\tau} \tau \omega \nu)$

The editio princeps was made in Florence in 1526 (Hephaestionis Enchiridion, Graece. Frorentiae, per Heredes Phillipi luntae). This work includes the Sapphic fragments:

Lobel-Page 49 / Voigt 49 / Gallavotti 43 / Diehl 40, 41 / Bergk 33, 34 (Heph. Ench. 7.7)

\footnotetext{
${ }^{42}$ Plut. Mor. 243 b, 622 c, 406 a

${ }^{43}$ Wilson, From Byzantium to Italy: Greek Studies in the Italian Renaissance, 1-2.

${ }^{44}$ Wilson, From Byzantium to Italy: Greek Studies in the Italian Renaissance, 134-136.
} 
Lobel-Page 82 / Diehl 80 / Cox 75 (Heph. Ench. 11.5)

Lobel-Page 102 / Voigt 102 / Diehl 114 / Bergk 90 (Heph. Ench.10.5)

Lobel-Page 110a / Voigt 110 / Diehl 124 / Bergk 98 (Heph. Ench. 7.6)

Lobel-Page 112 / Diehl 128 (Heph. Ench.15.26)

Lobel-Page 115 / Diehl 127 (Heph. Ench.7.6)

Lobel-Page 117 / Diehl 129 (Heph. Ench.4.2)

Lobel-Page 128 / Diehl 90 (Heph. Ench. 9.2)

Lobel-Page 130 / Diehl 137 / Voigt 130 / Bergk 40 (Heph. Ench. 7.7)

Lobel-Page 131 / Diehl 137 / Voigt 130 / Bergk 41 (Heph., Ench.7.7, v.ad fr. 130)

Lobel-Page 132 / Diehl 152 / Cox 82 (Heph. Ench.15.18)

Lobel-Page 140? / Bergk 62? / Voigt 140? / Cox 59 (Heph. Ench. 10.4)

Lobel-Page 154 / Diehl 88 / Cox 49 (Heph. Ench. 11.3)

Lobel-Page i.a. 16 / Diehl 93 / Cox 50 (Heph. Ench.11.3,5)

\section{4) Stobaeus, Anthology}

Stobaeus was published in Basel in 1532 by Hieronymus Frobenius under the responsibility of Sigismundus Gelenius. This edition contains only some of the second part of the work, the Florilegium. The full edition of Florilegium was made in 1535 or 1536 in Venice by Bartolomeo Zanetti and Victor Trincavelius. Eclogues were printed later (1575). In the work of Stobaeus the Sapphic fragment Lobel-Page 55 / Voigt 55 / Diehl 58 / Bergk 68 / Cox 65 (Strob. 3.4.12) survives.

\section{5) Athenaeus, Deipnosophists ( $\Delta \varepsilon \iota \pi \nu \circ \sigma \circ \varphi 1 \sigma \tau \alpha i)$}

The epitome of the 15 volumes of the Deipnosophists had a great impact on Renaissance Italy because of the information contained about the daily life of ancient Greeks, such as their nutrition and social conditions, as well as because of the numerous references to unknown writers who were attracting the interest of the intellectuals. Indicatively, Jakob Questenberg, a papal official, in 1490, made two transcripts of the Deipnosophists ${ }^{45}$. In August 1514, Athenaeus was published by Aldus Manutius, edited by Marcus Musurus (Deipnosophistae, Ed. Marcus Musurus, Venetius: Aldum Manutium et Andream Torresanum, 1514). There is also another edition of Deipnosophists in 1535 in Basel (Athenaei, Dipnosophistarum, hoc est argute sciteque in convivio disserentium, lib XV, Ed Iacobo Bedroto, Christiano Herlino, Basileae: apud I. Valderum, 1535).

${ }^{45}$ Wilson, From Byzantium to Italy: Greek Studies in the Italian Renaissance, 98. 
This work of Athenaeus includes the following Sapphic fragments:

Lobel-Page 57 / Diehl 61 / Cox 67 / Bergk 70 (Athen. 21bc)

Lobel-Page 82 / Diehl 80 / Cox 75 (Athen. 15. 674e)

Lobel-Page 122 / Diehl 111 (Athen. 12.554b)

Lobel-Page 138 / Diehl 151 (Athen. 13.564d)

Lobel-Page 141/ Cox 47 (Athen. 10.425d)

Lobel-Page 143 / Diehl 118 (Athen. 2.54f)

Lobel-Page 160 / Diehl 11 / Cox 11 (Athen. 13.571d)

Lobel-Page 166 / Diehl 105 / Bergk 56 (Athen. 2.57d)

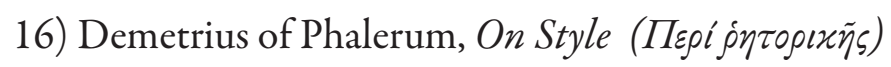

The book was published for the first time in 1552 (Demetrius Phalereus, De Elocutione: studio P. Victorii, Gr. Editio Princeps, Florent, apud Juntas). In this work the following Sapphic fragments are included:

Lobel-Page 104a / Voigt 104a / Diehl 120 / Bergk 95 / Cox 92 (Demetr. Eloc. 141)

Lobel-Page 105c / Voigt 105b / Diehl 117 / Bergk 93 / Cox 91 (Demetr. Eloc. 106)

Lobel-Page 106 / Diehl 115 (Demetr. Eloc. 146)

Lobel-Page 114 / Diehl 131 / Cox 104 (Demetr. Eloc.140)

Lobel-Page 156 / Diehl 138 / Cox 115 (Demetr. Eloc. 161s.)

Cox 168 (Demetr. Eloc.164)

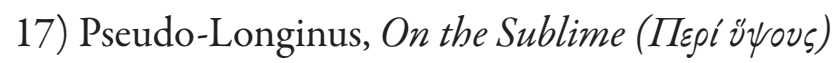

In 1554, Frascesco Robortello published in Basel the work On the Sublime, attributing it to Longinus (Dionysi Longini rhetoris praestantissimi free of grandio sublimiorationis genere ... as adnotationibus). This work includes the Sapphic fragment Lobel-Page 31 / Voigt 31 / Gallavotti 2 / Diehl 2 / Bergk 2 (Long. De subl. 10-3-3). However the work $O n$ the Sublime was already widespread in Italy by manuscripts in the first half of the 16th century: in addition to the Parisinus Graecus 2036 codex, dated back to the 10th century, there are a lot of manuscripts of the work from copies made in Renaissance by Bessarion, Janus Lascaris, Pietro Vettori, Ugolino Martelli, Diego Hurtado de Mendoza and others ${ }^{46}$.

\footnotetext{
${ }^{46}$ Refini, "Longinus and poetic imagination in Late Renaissance Literary Theory", 34-35.
} 
18) Maximus Tyrius, The Dissertations (Dissertationes)

The works of Maximus Tyrius are recorded in the Vittorino da Feltre's manuscript catalogue of 1445 , together with other authors, including Synesius ${ }^{47}$. However, there was no edition of Maximus until 1557, when he was published by Henricus Stephanus in Paris. Maximus Tyrius (18.9) records the Sapphic fragment Lobel-Page 150 / Diehl 109.

\section{Conclusion and further discussion}

It was attempted in this article to write down the way of the reception of Sappho's personality in the Renaissance, in parallel to a systematic and exhaustive presentation of the Sapphic verses reappeared in a large number of early publications of Ancient Greek authors from the mid $15^{\text {th }}$ until the mid $16^{\text {th }}$ century. Through the parallel study of these two factors it was exposed that Sappho has a strong presence in the Renaissance: on one hand she is a symbol and model of the female creator, an fact which does not emerge only from the knowledge of her verses but rather from an image of hers created by a literary tradition rooted in antiquity; on the other hand within one century her work starts to arise through the printed editions, which reproduce her fragments. So certain questions are raised as follows: how did the publication of the fragments change the understanding of Sappho? Did they confirm details of her life known from the biographical tradition? Were they the first primary sources on Sappho to become known in the West?

The current article could be the stimulus for:

1) a further study of the dissemination of the Sapphic work through the study of not only the early editions but also of the manuscripts on which the editions were based so that an earlier transfer of the Sapphic work would appear.

2) a study of the precise way the early editions fed the scholars and artists of the Renaissance with the knowledge of the Sapphic work.

3) a study of the extent of the effect of the dissemination of the Sapphic fragments to the already established biographical tradition concerning Sappho.

I hope and believe that the current study would be a prerequisite for a deeper sight in the mentioned research fields and help the prospective researcher to refer more accurately to the editions which filled in the Renaissance the Italian salons and academies, in order to study certain effects to circles, intellectuals and artistic works.

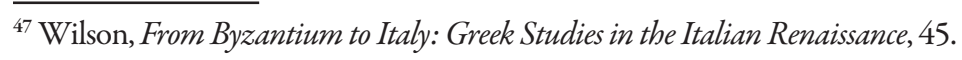




\section{Bibliography}

Andreadis, Harriett, Sappho in Early Modern England: Female Same-Sex Literary Erotics 1550-1714, Chicago: University of Chicago Press, 2001.

Bergk, Theodor (ed.), Poetae lyrici graeci, Lipsiae : Apud Reichenbachios, 1843.

Braund, Susanna, "The Metemphychosis of Horace: the reception of the satires and epistles", in: Gregson Davis (ed.), A Companion to Horace, Malden: Blackwell, 2010, 367-390.

Campbell, David A. (ed.), Greek Lyric: Volume I. Sappho and Alcaeus (Loeb Classical Library, no. 142), Cambridge: Harvard University Press, 1982.

Cox, Edwin Marion, The poems of Sappho with historical and critical Notes, Translations and a Bibliography, London: Williams and Norgate - New York: Charles Scribner's Sons, 1925.

Davies, Malcolm (ed.), Poetarum Melicorum Graecorum Fragmenta, vol. I. Alcman Stesichorus Ibycus, Oxford: Oxford University Press, 1991.

Dickey, Eleanor, Ancient Greek Scholarship: A Guide to Finding, Reading, and Understanding Scholia, Commentaries, Lexicas, and Grammatical Treatises: From Their Beginnings to the Byzantine Period, Oxford: Oxford University Press, 2007.

Diehl, Ernest (ed.), Anthologia Lyrica Graeca, Leipzig: Teubner, 1936.

Franklin, Margaret, Boccaccio's Heroines: Power And Virtue in Renaissance Society, New York: Routledge, 2017.

Greene, Ellen (ed.), Re-Reading Sappho: Reception and Transmission, California: University of California Press, 1996.

Hallett, Judith P., "Sappho and her Social Context: Sense and Sensuality”, Signs, 4:3, 1979, 447-464. Kolsky, Stephen, The Ghosts of Boccaccio: Writings on Famous Women in Renaissance Italy, Turnhout: Brepols, 2005.

Kock, Theodor (ed.), Comicorum Atticorum Fragmenta, Leipzig: B.G. Teubner, 1880-1888.

Lefkowitz, Mary R., "The Pindar Scholia”, The American Journal of Philology, 106:3, 1985, 269-282.

McKinney Brenner, Carla et al., The inquiring eye: Classical mythology in European Art, Washington: National Gallery of Art, 1996.

Miller, Clarence H. (ed.), The Complete Works of St. Thomas More, The Latin Poems, Yale: Yale UP, 1984.

Morrison, Mary, "Henri Estienne and Sappho", Bibliothèque d'humanisme et Renaissance, 24, 1962, 388-391.

Most, Glenn W. "Reflecting Sappho", Bulletin of the Institute of Classical Studies, 40, 1995, 15-38.

Nagy, Gregory, "Copies and Models in Horace Odes 4.1 and 4.2", Classical World, 87, 1994, 415-426.

Page, Denys \& Lobel, Edgar (eds), Poetarum Lesbiorum fragmenta, Oxford: Clarendon Press, 1955.

Page, Denys, Sappho and Alcaeus: an introduction to the study of ancient Lesbian poetry, Oxford: Clarendon Press, 1959.

Page, Denys (ed.), Poetae Melici Graeci, Oxford: Clarendon Press, 1966.

Page, Denys, Supplementum lyricis Graecis, Oxford: Clarendon Press, 1974.

Parker, Holt, "Sappho Schoolmistress", Transactions of the American Philological Association, 123, 1993, 309-351.

Penrose, Walter, “Sappho's Shifting Fortunes from Antiquity to the Early Renaissance", Journal of Lesbian Studies, 18:4, 2014, 415-436.

Lazzeri, Elisabetta (ed.), Poliziano, Angelo, Commento inedito all'epistola ovidiana di Saffo a Faone, Firenze: Istituto nazionale di studi sul Rinascimento, 1971.

Quondam, Amedeo, “Francesco Petrarca”, in: Giulio Ferroni (ed.), Il contributo italiano alla storia del 
pensiero: Letteratura, Roma: Istituto della Enciclopedia Italiana, 2018, 48-59.

Refini, Eugenio, "Longinus and poetic imagination in Late Renaissance Literary Theory", in: Caroline van Eck, et al. (eds), Translations of the Sublime: The Early Modern Reception and Dissemination of Longinus' Peri Hupsous in Rhetoric, the Visual Arts, Architecture and the Theatre, Leiden and Boston: MA: Brill, 2012, 33-54.

Reynolds, Margaret, The Sappho Companion, London: Vintage, 2001.

Voigt, Eva-Maria (ed.), Sappho et Alcaeus: fragmenta, Amsterdam: Amsterdam : Polak and Van Gennep, 1971.

West, M. L. (ed.), Delectus ex iambis et elegis Graecis, Oxford: Clarendon Press, 1980.

Wilson, N.G., From Byzantium to Italy: Greek Studies in the Italian Renaissance, 2nd Edition, London: Bloomsbury Academic, 2017.

Yatromanolakis, Dimitrios, "Alcaeus and Sappho", in Felix Budelmann (ed.), The Cambridge Companion to Greek Lyric, Cambridge: Cambridge University Press, 2009, 204-226. 